\title{
Imaginário coletivo e memes nas redes sociais digi- tais: o caso da Escola da Depressão
}

\author{
Raphael Alves da Silva \\ Universidade Federal Rural de Pernambuco \\ Flavia Mendes de Andrade e Peres \\ Universidade Federal de Pernambuco
}

\section{Resumo}

presente trabalho busca compreender a articulação entre a constituição de um imaginário coletivo sobre a escola e sua materialização no gênero discursivo "meme", nas redes sociais digitais. Trata-se de um estudo orientado pela etnografia virtual, com base em um corpus analítico situado na página do Facebook Escola da Depressão. Entre janeiro e março de 2017 , foram realizadas imersões no espaço virtual com o objetivo de observar as práticas de uso e analisar os memes, publicados na página em foco. O panorama estudado indica que suas manifestações discursivas realçam, quase sempre, uma visão pessimista sobre a escola, a qual não é percebida como espaço para manifestação de valores igualitários e liberdade de pensamento. Com base na perspectiva dos estudantes, essas materialidades enunciam situações que caracterizam, ressignificam e criticam o cotidiano escolar com o uso do humor; deslegitimam o papel educacional e transformador da escola, mas não apresentam propostas para possíveis rupturas

88 com o modelo imposto.

Palavras-chave: Escola. Redes sociais. Memes. Imaginário coletivo.

\section{Imaginary collective and memes in digital social networks: the case of the School of Depression}

\section{Abstract}

The present work seeks to understand the articulation between the constitution of a collective imaginary about school and its materialization in the discursive genre "meme", in digital social networks. It is a study oriented by virtual ethnography, based on an analytical corpus located on the Facebook page School of Depression (Escola da Depressão). Between January and March 2017, we perform immersions in the virtual space with the purpose of observing the usage practices and analyzing memes published in the page in focus. The studied panorama indicates that its discursive manifestations almost always emphasize a pessimistic view about school, which is not perceived as a space for the manifestation of egalitarian values and free thought. Based on the students' perspective, these materialities state situations that characterize, resignify and criticize school every day with the use of humor; they delegitimize the educational and transformative role of school, but do not present proposals for possible ruptures with the imposed model.

Keywords: School. Social networks. Memes. Collective imaginary. 


\section{Llmaginario colectivo y memes en las redes sociales digitales: el caso de la Escuela de la Depresión}

\section{Resumen}

El presente trabajo busca comprender la articulación entre la constitución de un imaginario colectivo sobre la escuela y su materialización en el género discursivo "meme", en las redes sociales digitales. Se trata de un estudio orientado por la etnografía virtual, con base en un corpus analítico ubicado en la página de Facebook Escuela de la Depresión (Escola da Depressão). Entre enero y marzo de 2017, se realizaron inmersiones en el espacio virtual con el objetivo de observar las prácticas de uso y analizados los memes publicados en la página en foco. El panorama estudiado indica que estas manifestaciones discursivas realzan casi siempre una visión pesimista sobre la escuela, la cual no es percibida como espacio para manifestación de valores igualitarios y libertad de pensamiento. Con base en la perspectiva de los estudiantes, esas materialidades enuncian situaciones que caracterizan, resignifican y critican el cotidiano escolar con el uso del humor; deslegitiman el papel educativo y transformador de la escuela, pero no presentan propuestas para posibles rupturas con el modelo impuesto. Palabras clave: Escuela. Redes sociales. Memes. Imaginario colectivo.

\section{Introdução}

As redes sociais digitais que temos, hoje, à disposição, como, por exemplo, o Facebook, Twitter e Instagram, são, indiscutivelmente, um dos maiores fenômenos culturais da atualidade. O surgimento de novas possibilidades técnicas de comunicação, como afirma Perruzo (2002), fez com que questões ligadas às noções de espaço e tempo, na vida dos sujeitos, passassem a sofrer alterações sem precedentes. Segundo Cardoso (2007, p. 29), o nosso mundo é "[... um mundo de comunicação mediada por tecnologias [...]", tornando-se evidente o quanto essas redes dinamizaram a utilização da internet e criaram espaços de concentração complexos, possibilitando a expressão de muitas vozes, antes ausentes de discussões político-sociais.

Tais redes possuem inúmeros caminhos para que os laços sociais que originam determinados agrupamentos sejam possíveis. Recuero (2009), ao discutir a construção das identidades em ambientes virtuais, atenta para o fato de que o anonimato, a incorporação de um vocabulário próprio e a possibilidade de reconstruir uma imagem são elementos fundamentais para a identificação dos atores como membros de determinada rede. Em face do exposto, podemos afirmar que uma rede social é sempre definida por dois elementos centrais: os atores (pessoas, instituições ou grupos; os nós da rede) e suas conexões 
(interações ou laços sociais) (WASSERMAN, FAUST, 1994; CARRINGTON, SCOT, WASSERMAN, 2005).

Os discursos nas redes sociais digitais, materializados, quase sempre, em textos verbais e imagens, nos permitem compreender a história do tempo presente, já que estão intrinsecamente relacionados com a forma como produzimos significados e construímos conhecimento. A escola, enquanto espaço legitimamente encarregado de provocar e propagar conhecimentos, parece ainda apresentar certa dificuldade em acompanhar os intensos processos interacionais, presentes em um mundo onde o apelo visual e o uso de imagens são recorrentes.

Ainda que a construção de imaginários coletivos não seja um fenômeno contemporâneo, e que sua existência não esteja atrelada aos contextos virtuais de interação, as redes sociais digitais parecem amplificar alguns discursos, ocasionando transformações nos processos e nas disseminações de imaginários. Entendemos, neste trabalho, que, com o advento da internet e das redes sociais, por volta do século XX e início do XXI, vários discursos, antes circunscritos a grupos sociais localizados, passassem a circular mais livremente, uma vez que as mídias sociais democratizam cada vez mais o saber

90 e a crítica. Esses discursos, materializados, quase sempre, em textos verbais e imagens, nos permitem compreender a história do tempo presente, visto que estão intrinsecamente relacionados à forma como construímos conhecimento. A escola, enquanto espaço legitimamente encarregado de provocar e propagar conhecimentos, parece demonstrar dificuldades em acompanhar os intensos processos interacionais, atualmente, presentes.

Estudos, como o de Valle (1997, p. 48), buscam compreender os antecedentes históricos da imaginação sobre a escola, a partir de diferentes tradições teóricas. Superando a visão conservadora, que via o imaginário apenas como "[...] agência de produção de falsas imagens, de ilusões, de visões deformadas da realidade $[\ldots]^{\prime \prime}$, a autora considera que o imaginário de uma sociedade leva em conta o fato de que ele representa uma força instituidora, unificadora da sociedade e, sempre dinâmico, aberto à produção do novo.

Este trabalho busca, com base na realização de uma etnografia virtual, compreender a articulação entre a complexa constituição de um imaginário coletivo sobre a escola e sua materialização nos memes publicados na página do Facebook chamada Escola da Depressão', um espaço onde a educação formal é imaginada por uma rede com mais de dois milhões de usuários. Ao 
focalizar em processos discursivos coletivizados, objetiva-se: perceber até que ponto os memes possibilitam ou restringem a atuação crítico-transformadora sobre os contextos escolares; e identificar, a partir das regularidades discursivas encontradas, como as ações e os comportamentos vivenciados no ambiente escolar são tematizados pelos membros daquela comunidade.

Nesse percurso, o artigo está estruturado da seguinte forma: inicialmente, discutimos o processo de consolidação dos espaços virtuais, conceituando-se e apresentando-se o gênero discursivo meme; depois, caracterizamos o conceito de imaginário coletivo, antes e depois do surgimento das redes sociais digitais, e suas relações com a discussão sobre escola na contemporaneidade; em seguida, tratamos da metodologia construída, o processo de categorização e organização do corpus analítico; finalmente, são evidenciadas algumas relações analíticas entre memes exemplares e os aspectos imaginários que constituem a Escola da Depressão.

\section{Redes sociais digitais e memes}

Estudos efetivados nos ambientes virtuais possibilitam a compreensão de significados variados atribuídos às coisas e pessoas, produzidos com base no ponto de vista de sujeitos e grupos ou comunidades que emergem nessas redes. Mediadas através de computadores, celulares e tablets, as interações estabelecidas na virtualidade não podem, como defende Hine (2004), ser analisadas dissociadas dos contextos mais amplos nos quais elas ocorrem. Essa mudança de perspectiva criou aquilo que se convencionou como ciberespaço. Lévy (2000) conceitua essa nova espacialidade como um lugar habitado pelos saberes, onde os indivíduos podem se manter interligados independentemente do local geográfico onde se situam.

Dessa maneira, são os sujeitos, com base nas trocas simbólicas, e nos discursos promovidos e permitidos pelos gêneros discursivos oriundos dessas plataformas, que constroem novos espaços de significação e criam delimitações territoriais que, apesar de mutáveis, são bastante necessárias para a constituição da inteligência coletiva, " [...] uma inteligência distribuída por toda parte, incessantemente valorizada, coordenada em tempo real [...]" (LÉVY, 2000, p. 28) que ocorre a partir do uso das tecnologias da informação e comunicação. 
Nesse espaço múltiplo, diverso e naturalmente complexo, os sujeitos deixaram de ser vistos apenas como agentes receptores de informação. Pelos alcances de interação e atuação, hoje são vistos como comunicadores ativos, criando e preservando campos de relações, com novas formas emergentes de interação na e pela linguagem. Assim, emergem novos gêneros discursivos, oriundos do "[.. ] uso integrado de diferentes recursos comunicativos, tais como linguagem [texto verbal], imagem, sons e música em textos multimodais e eventos comunicativos" (VAN LEEUWEN, 2011 , p. 668), que desafiam pesquisadores no mundo todo à criação de métodos analíticos aos fenômenos também novos.

meme, um dos gêneros mais presentes, nas redes sociais digitais, exemplifica esses processos de enunciação emergentes e criativos, já que, de forma bastante dinâmica, possibilita a elaboração e a propagação de discursos e ideologias. Já apresentando uma gramática própria, como podemos ver nos estudos realizados por Shifman (2013), o caráter polifônico e rotativo dos memes cria um contexto bastante desafiador para quem se dispõe a pesquisá-los. Aristimuño (2014) afirma que a riqueza dos memes da internet reside no fato de eles permitirem que fronteiras simbólicas sejam rompidas, na mesma

92 medida em que as identidades sociais dos sujeitos, nos processos virtuais interacionais, sejam forjadas ou reorganizadas.

Os memes, nos contextos digitais, geralmente carregados de humor, geram engajamento, mobilização e permitem que os sujeitos disseminem e propaguem ideias, cujo alcance é cada vez mais difícil de prever. Neste trabalho, optamos pela nomenclatura rede social digital, por entender que elas são sociais, ou seja, capazes de permitir a colaboração e interação de grandes grupos e, concomitantemente, são mídias, já que devem ser vistas como meios de transformação de informação e de conteúdo, segundo defende Torres (2009). Este artigo deixa explícito que, tais redes alimentam e são alimentadas pelo imaginário coletivo e permitem que vozes social e historicamente silenciadas como, por exemplo, as dos alunos, possam se manifestar com mais liberdade. Nessas redes, eventos interativos intensos permitem que esses mesmos sujeitos insiram, criem e propagem discursos, isto é, produzam sentido.

Antes da democratização do acesso a essas redes, autores como Castells (2006, p. 75), por exemplo, afirmavam que a invenção da internet reforçou "[...] também a ideia de que a cooperação e a liberdade de informação podem ser mais propícias à inovação do que a competição e os direitos de 
propriedade". Recuero (2009), ao resgatar estudos realizados por Wasserman e Faust (1994), aponta para o surgimento de um tipo específico de rede, as chamadas Redes de Filiação, ou Redes de Dois Modos, que são, em linhas gerais, agrupamentos formados por um número determinado de atores relacionados por conexões em que o sentimento de pertencimento se faz presente.

Sobre a constituição dos sujeitos nesse ambiente extremamente mutável, Cordeiro (2016) reforça que é o dinamismo, realizado pelos próprios indivíduos em suas ações e atividades relacionais, que criará um cenário amplamente interativo em que trocas constantes entre o ev e o outro serão consolidadas. Examinando, especificamente, o que está sendo produzido por páginas como a Escola da Depressão, onde as interações giram em torno do que é a escola, no imaginário coletivo dos seguidores, podemos, como aponta Souza (2009), olhar para os atores sociais dentro de contextos específicos de interação.

meme da internet é, hoje, um dos gêneros discursivos mais presentes no ambiente virtual. Enquanto unidade discursiva, ele possibilita ou restringe a atuação crítico-transformadora sobre os mais diversos contextos, e é considerado um dos maiores fenômenos das mídias digitais. Para entender melhor o seu processo de formação e como esse gênero passou a ganhar força entre os usuários das redes, é necessário compreender o seu significado e as relações históricas que carregam de sentido o seu nome, cuja etimologia vem do grego mímesis (imitação).

A primeira definição de meme está ligada ao conceito criado e defendido pelo escritor e filósofo britânico Richard Dawkins no final da década de 1970. $\bigcirc$ autor, em seus estudos voltados para as questões biológicas da evolução, defendia que as características fenotípicas de um gene do ser humano, embora limitado ao seu corpo, pode propagar-se no ambiente. Esse pequeno gene, essa unidade que pode ser ampliada nas suas relações com o mundo exterior, que Schuabb (2016) chama de "replicadora", por possuir a capacidade de criar cópias de si mesma (SCHUABB, 2016, p. 13), serviu como base teórica para que ele abrisse caminho para o que hoje se denomina memética, ou seja, o conjunto de estudos realizados sobre os memes. É o próprio Dawkins quem diz:

Precisamos de um nome para o novo replicador, um substantivo que transmita a idéia de uma unidade de transmissão cultural, ou uma unidade de imitação. 'Mimeme' provém de uma raiz grega 
adequada, mas quero um monossílabo que soe um pouco como 'gene'. Espero que meus amigos helenistas me perdoem se eu abreviar mimeme para meme. Se servir como consolo, pode-se, alternativamente, pensar que a palavra está relacionada à 'memória', ou à palavra francesa même (DAWKINS, 1979, p. 122-123).

Dawkins, em seus estudos, aponta para algumas características que definem o sucesso de replicação cultural de um meme. São elas; a fecundidade, a longevidade e a fidelidade de cópia, ou seja, aquilo que, de alguma maneira, é mantido durante o processo de replicação. Com o passar do tempo, autores, como Susan Blackmore (2000) e Daniel Dennett (1996), passaram a teorizar sobre a semente plantada por Dawkins, buscando novos caminhos de abordagem, na tentativa de consolidar a memética enquanto ciência. A academia e outras comunidades produtoras de conhecimento, por sua vez, continuam enxergando o posicionamento desses teóricos com bastante resistência. $O$ argumento principal é o de que tanto Blackmore, quanto Dennet que especificamente, se voltaram para o diálogo entre religião e meme, utilizam formulações bastante contraditórias e não conseguem fundar uma episteme para o objeto em questão. Essa é uma discussão que vem sendo aprofundada 94 em outras esferas, visto que o fazer ciência depende, intrinsicamente, desse jogo de valores, com teses contestadas e defendidas.

Todos os dias, redes, como o Facebook e o Twitter, são espaços propícios para a propagação de memes. Apesar de criados por inúmeros sujeitos, muitos deles se multiplicam, rapidamente, como organismos, com base em uma rede ininterrupta de compartilhamentos. Até meados da década de 1990, não havia correlação entre esse termo e a unidade digital que conhecemos, hoje, e nunca foi possível apontar, oficialmente, quem utilizou o termo meme pela primeira vez para se referir ao gênero que ganhava cada vez mais espaço nas embrionárias redes sociais digitais. Sabemos que a grande virada no que diz respeito ao tipo de conteúdo disponível, na internet, ocorreu quando o público passou, também, a atuar enquanto produtor, deixando de assumir, em sua totalidade, o papel de consumidor passivo. Sobre a participação mais ativa dos sujeitos no ciberespaço, Jenkins aponta que

Cada um de nós constrói a própria mitologia pessoal, a partir de pedaços e fragmentos de informações extraídos do fluxo midiático e transformados em recursos através dos quais compreendemos nossa vida cotidiana. Por haver mais informações sobre 
determinado assunto do que alguém possa guardar na cabeça, há um incentivo extra para que conversemos entre nós sobre a mídia que consumimos (JENKINS, 2009, p. 30).

Estudiosos, como Souza (2013, p.131), defendem que os temas abordados pelos memes geralmente são "[...] provenientes em grande parte de outros canais midiáticos, sendo estes a televisão, os jornais impressos e o rádio". Fontanella (2009), ao discutir o processo de elaboração de um meme e a intencionalidade de quem o produz, diz que ele é caracterizado, principalmente, por dois aspectos: combinação de permanência de um elemento replicador original; mutação, fruto de seu aproveitamento por diferentes usuários para a criação de versões.

Apesar de sofrerem um "processo viral", termo novamente emprestado da biologia para simbolizar o tipo de mensagem que pode alcançar grandes proporções na rede, como defende Barrichello e Oliveira (2010), os memes não podem ser vistos, apenas, como unidades propagadoras de discursos, mas também sofrendo mutações diversas e incontroláveis, de modo que é quase impossível determinar o seu elaborador, como aponta Burgess e Green (2009). Isso significa, por fim, que todo meme é resultado de um processo de imitação. Eles são produzidos com base em uma narrativa embrionária que é replicada, adquirindo novos sentidos. Como resume Shifman (2013), eles moldam pensamentos, formas de comportamento e ações de grupos sociais.

Esse processo de recriação, nas redes digitais, tem forte ligação com o sentimento de pertencimento a determinado grupo. Martino discute sobre a capacidade dos memes no que diz respeito à criação de laços:

Reelaborar um "meme" é ser parte de uma comunidade talvez anônima, mas não menos forte. Memes são compartilhados em redes sociais digitais, de certa maneira, pelo mesmo motivo que pessoas contam piadas ou histórias que ouviram: para fazer parte do grupo [...] (MARTINO, 2015, p. 179).

Consideramos perceptível que, para fazer sentido dentro dos jogos discursivos permitidos pelas redes sociais digitais, o meme precisa se constituir dentro da realidade daqueles que podem fazer uso do seu discurso. Ele, geralmente, agrega uma ou mais motivações, a princípio, individuais ou de um pequeno grupo que, evidentemente, após milhares de compartilhamentos, acabam se tornando um traço cultural daquela comunidade. 
Com frequência, encontramos, nas redes sociais digitais, memes que difundem discursos, utilizando o humor, para falar sobre diversos campos da vida social. Eles são, como defende Possenti (2005, p. 82), materiais ricos que nos ajudam a compreender elementos culturais. Julgamos importante frisar que o autor, também, aponta que o "[...] discurso humorístico, nos diversos gêneros discursivos em que se materializa, faz apelo a um saber, a uma memória - mas não necessariamente a uma cultura específica". É por isso que a maior parte dos textos humorísticos disseminados, nas redes digitais, exploram conceitos ou fatos já conhecidos pelos sujeitos, ou seja, eles "[...] não se caracterizam por difundir discursos novos, "[...] mas por explorar de forma específica discursos correntes" (POSSENTI, 2005, p. 82).

Dessa maneira, o discurso humorístico pode levantar questões humanas essenciais, mostrando como o cultural, o imaginário, o inconsciente, o político e o linguístico convergem e podem promover atitudes de adesão e resistência. $\bigcirc$ humor, como pontua Justo (2006), deve ser encarado como uma das formas legítimas de mediação com o mundo; para isso, ele precisa ser adequado ao usuário, assumindo, muitas vezes, um tom político, sarcástico e/ ou caricatural. Isso ocorre porque, como afirma Possenti (2005, p. 37), as pia96 das, geralmente, são enunciados que "[...] só podem ocorrer num solo fértil de problemas, como os das zonas discursivas assinaladas acima, solos cultivados durante séculos de disputas e de preconceitos".

A escola, enquanto instituição social, é um terreno propício para a disseminação de discursos e, por estar presente no cotidiano de inúmeras pessoas nas culturas escolarizadas, elicia processos de significação. Como percebemos nas análises, os processos de significação eliciados, com base nas culturas escolarizadas, são, antes de tudo, o resultado dos sentidos emergentes do imaginário coletivo que, como sabemos, circulam sócio historicamente.

\section{Escola e Imaginários coletivos}

Estudos realizados por Durand (1997) foram pioneiros no sentido de apontar para uma nova trajetória sobre os estudos do imaginário. Apoiado na antropologia, o autor procurou pensar sobre os processos de temporalização das imagens, olhando, especificamente, para aquelas que participam da constituição do pensamento social e para as que regulam, de certa maneira, o comportamento dos sujeitos. A grande contribuição inicial de Durand (1997) 
foi deslocar o conceito de imaginário para as ciências sociais, já que, quase sempre, esse tema foi visto com uma "desconfiança iconoclasta" pela filosofia fundamental. Muitos estudiosos viram o imaginário como objeto de reflexão, porém ele, quase sempre, era visto como um lugar de identificação e de relações duais, opostas e difusas. Para Lacan (2005), por exemplo, o imaginário ajuda a compor a realidade humana, sobretudo, como espaço para a teatralização das ilusões do ev; em outras palavras, ele criava pontos de interseção entre o real e o simbólico, mas opera dentro de sua própria instância.

Durand (1997) vai se opor, fortemente, a essa concepção de imaginário, e, no seu famoso trabalho chamado As estruturas antropológicas do imaginário, não só critica as abordagens com viés mais dualista, como também procura questionar as inúmeras posturas conceituais adotadas até aquele momento. $\bigcirc$ imaginário, para Durand (1997, p. 14), é, na verdade, "[...] o conjunto das imagens e das relações de imagens que constitui o capital pensado do homosapiens". Isso significa que a imaginação é parte constitutiva do pensamento humano, ou seja, ela se manifesta como atividade capaz de criar e transformar a realidade. A ideia de que pensamento e imagem não podem ser vistos, dicotomicamente, vem do fato de que os signos, símbolos e todos os componentes que atuam nos processos de significação estão de forma dinâmica interligados aos sentidos carregados pelas imagens, o que levará Durand ( 1997 ) a postular sobre uma "ciência do imaginário".

Com base nesses pressupostos, a imagem passa a ser mais bem compreendida nas ciências sociais, sendo considerada uma manifestação do invisível, do não concreto. Ao enxergar o imaginário enquanto um "museu" vivo onde estão depositadas as "[...] imagens passadas, possíveis, produzidas e a produzir, nas suas diferentes modalidades da sua produção" (DURAND, 1984 , p. 3) compreende-se melhor a relação estabelecida entre os sujeitos e os processos históricos que estão intrínsecos ao desenvolvimento de qualquer sociedade. Isso mostra que, apesar de constituído e constituinte dos sujeitos, o imaginário não se desenvolve em torno de imagens livres e aleatórias, existe uma lógica composicional, um caminho possivel no qual um mundo de representações simbólicas emerge. Se para Durand (1984, p. 66), a imaginação "[...] é o trajeto antropológico de um ser que bebe numa bacia semântica $[\ldots]^{\prime \prime}$, ou seja, uma espécie de lago com significados, oriundos do encontro das águas, para Maffesoli (200 1) ele se estabelece a partir do vínculo social. 
Para o autor, o imaginário é uma espécie de aura, que, assim como a atmosfera, não pode ser vista, mas pode ser sentida.

Ancorado nos postulados e nas teorias de Bachelard e do próprio Durand, de quem foi discípulo, Maffesoli (2001) vai admitir a existência de dois tipos de imaginário, o individual, que ocorre a partir dos processos de identificação, apropriação e distorção daquilo que vem do outro; e o coletivo, este geralmente estruturado a partir do que ele chama de contágio, ou seja, da aceitação, disseminação e imitação daquilo que vem do outro. Ao afirmar que "o imaginário estabelece um vínculo", Maffesoli (2001) reforça a tese de que, como uma espécie de cimento, o imaginário liga, ou seja, une os sujeitos em algum nível numa mesma atmosfera, a partir do que o autor define como processo de tribalização das sociedades.

Com base nesse pressuposto, é inviável enxergar o imaginário como um fenômeno de ordem apenas individual. É preciso compreender que a imaginação não pode ser lida exclusivamente como uma oposição do sujeito ao real e sim como parte de um processo que envolve uma série de imagens mentais, discursos, interações simbólicas, culturas e ideologias. É por isso que Maffesoli (2001, p. 80), ao pensar nas tecnologias da informação, reforça que "[...] 98 o imaginário, enquanto comunhão é, sempre, comunicação" e que a "[...] internet é uma tecnologia da interatividade que alimenta e é alimentada por imaginários" (MAFFESOLI, 2001, p. 80).

Maffesoli (2001) levará a palavra imaginário para um campo de sentido onde ele possa ser entendido como um tipo de catalisador, uma energia criada e pertencente aos grupos a partir das sensações, afetos, lembranças e estilos de vida que compartilham. Isso significa que, se por um lado, a construção do imaginário do sujeito ocorre a partir das identificações, apropriações e distorções estabelecidas em função do outro, o imaginário social, da coletividade, será resultado de processos movidos por contágio, ou seja, pelas aceitações, imitações e disseminações que permeiam a vida dentro da tribo.

Imaginário Coletivo construído, historicamente, antes do processo de democratização das mídias digitais, é resultante de um longo processo que, como pontua Valle (1997, p. 34), está intimamente relacionado "[...] à sua existência material, histórica, política, ideológica e legal". Com o surgimento da internet e, posteriormente, a criação e democratização das redes sociais digitais, novas práticas discursivas sobre esse objeto passaram a ser 
construídas e midiatizadas pelos sujeitos. Esse jogo interativo, percebido no esquema a partir da interseção entre o imaginário coletivo sobre a escola antes e depois das materializações discursivas no ciberespaço, é estruturado em níveis discursivos cada vez mais complexos, espaços que nos fornecem, materialmente, alguns dos elementos que constituem o imaginário construído a partir das relações presentes no ciberespaço; terreno fértil para os estudos descritivos, analíticos e reflexivos podem ser realizados. Importa-nos ressaltar que essas duas maneiras de imaginar a escola não podem ser vistas de forma dicotômica, pelo contrário, existem muitas interseções entre elas, já que ambas são reflexos dos processos híbridos e genuínos de subjetivação que criam um polo contínuo que não enxerga barreiras significativas, no que diz respeito às manifestações discursivas, entre aquilo entendido por real ou virtual.

À luz da discussão de Foucault (1 999) sobre a transmissão e a naturalização do poder, podemos compreender que a escola, em suas estruturas físicas e modos de organização, se transforma em uma "instituição de sequestro", ou seja, um espaço capaz de capturar os corpos e submetê-los a tecnologias de poder disciplinar. Ao discutir os processos de dominação, Foucault (1999, p. 72) defende que o poder "[...] produz realidade, produz campos de objetos e rituais de verdade $[\ldots]$ ", o que reforça a associação que ele propõe entre a prisão e a escola, visto que, em ambas, podemos identificar uma disposição geográfica em que os espaços hierárquicos e punitivos, como as coordenações e diretorias, são facilmente identificáveis, bem como o cumprimento de horários rigidamente controlados. Para o autor, o funcionamento histórico da escola esteve atrelado à ideia de vigilância, controle e recompensa, disciplinando os corpos dos sujeitos "numa universalidade punível-punidora".

São esses processos contínuos de arranjos educacionais, regularizados e democratizados a partir das necessidades sociais e das novas concepções de sujeito emergentes dos contextos históricos, os principais construtores de um imaginário coletivo sobre a escola. Importa-nos frisar que a implementação dos modelos educacionais não pode, evidentemente, ser encarada de forma reducionista. A educação é um fenômeno em constante movimento, e suas matrizes ideológicas e simbólicas são bastante flexíveis. Isso fez com que ela fosse vista, até hoje, como um dos principais instrumentos de transformação das estruturas sociais, mesmo também sendo determinada e controlada por essas mesmas estruturas. 
Nesse processo constante de ressignificação, as tecnologias ocuparam sempre um lugar de destaque, já que com a expansão do uso da internet e da popularização dos aparelhos celulares, surgiram novas formas de significar o mundo, na escrita e na fala. Os processos de troca de conhecimento passaram a sofrer mudanças concretas, influenciando e sendo influenciado por comunicações em rede que se propagam com enorme velocidade. Esse momento de descentralização, ainda em andamento, tem levantado questionamentos importantes sobre o papel efetivo da escola, permitindo que os agentes participantes desse contexto avaliem e reconstruam suas próprias práticas educativas.

imaginário, ao ser visto como uma rede volátil, estabelece relação direta com aquilo que é compartilhado não só no plano concreto, mas também no virtual. Sendo os textos verbais e imagens formas históricas que possibilitam a representação do mundo, descrevendo os objetos, dando sentido amplo ou restrito àquilo que apreendemos enquanto realidade, é natural que participem, ativamente, das narrativas imaginárias. No processo que envolve a consolidação temporária desses imaginários, a hipertextualidade ocupa um lugar de destaque, visto que participa, ativamente, das manipulações repletas de iconi100 cidade realizada nas mídias.

Se os imaginários preexistem aos sujeitos e podem ser compartilhados a partir das trocas que eles estabelecem no coletivo, podemos inferir que a disseminação das redes sociais digitais pelo mundo transformou ainda mais os sujeitos em inseminadores de imaginários. Consideramos importante pontuar que o conceito de imaginário não deve ser restrito ao ato de imaginar sobre mundo, ele atua mais como um conector obrigatório pelo qual as representações são construídas, permitindo, assim, que os sujeitos sintam-se pertencentes a algo. É por isso que, para Maffesoli (2001), o imaginário instala-se por contaminação, criando impulsos que levam os sujeitos a realizar ações concretas, como, por exemplo, a materialização dos discursos que permeiam os dispositivos informativos e os artefatos visuais.

Os enunciados que ganham materialidade, nas redes sociais, quando categorizadas em gêneros discursivos, cada um com suas especificidades, se tornam elementos passíveis de análise e descrição, sendo vistos, quase sempre, como elemento importante da cultura, neste caso, cibernética. Mas como, de fato, a tecnologia permite a disseminação de imaginários? Para Maffesoli (2001), o imaginário é o estado de espírito de um grupo, de um país, de 
um Estado, nação, de uma comunidade, logo, é natural que os processos interacionais, permitidos pelas redes sociais digitais, amplamente organizados em páginas, grupos e perfis individuais, também reflitam e representem parte daquilo que é imaginado pelos sujeitos na coletividade.

Essas muitas dimensões imaginárias podem nos ajudar a perceber como foi concedida à escola uma importância tão permanente, como aponta Valle, é

[...] como instituição eminentemente imaginária que a escola se edifica, em sua origem, como projeto político de uma sociedade; e é pela capacidade de permanente reconstrução de seu sentido imaginário que ela pôde resistir ao tempo como instituição duravelmente enraizada na vida social (VALLE, 1997, p. 13).

Com base nesse raciocínio, podemos refletir sobre como as unidades de sentido e os processos identitários foram estabelecidos entre aqueles que podiam participar, ativamente, da política educacional e aqueles que, por muito tempo, foram vistos, apenas, como componentes passivos, como receptores. A construção do imaginário sobre a escola resulta, no primeiro momento, das imposições colocadas por aqueles que detinham poder, que desenharam um modelo institucional voltado para a capacitação de uma mão de obra especializada, essencial para a consolidação do projeto econômico, voltado para o acúmulo do lucro.

Apesar de não ser um consenso entre educadores, muitos estudos sobre a história da educação, em particular sobre a do Brasil, como os de Saviani (2004), revelam como a criação de um sistema nacional de ensino não significou, necessariamente, uma democratização do saber, visto que, com a intenção de fazer da escola pública um condutor para o mercado de trabalho, as políticas conduzidas por uma classe social dominante passaram a favorecer apenas uma parcela da sociedade, provocando, diretamente, o sucateamento sistêmico e organizado da rede pública de ensino, criando, finalmente, as bases para a consolidação dos modelos privados de educação formal.

Valle (1997, p. 4), ao olhar para essas questões, discute como, na história da educação brasileira, o movimento pela "desideologização" da escola alimentava-se da "ilusão de que era possivel submeter a instituição" a uma "radical racionalização". Ao difundir ideias estrategicamente pensadas para atender ao capital, essa crise política do imaginário sobre a escola, que 
conseguiu, de distintas maneiras, silenciar as vozes dos oprimidos, provocou o surgimento de dois sentimentos que passaram a conviver sistematicamente, o primeiro, de resistência, organizado em movimentos políticos, como os grêmios estudantis; o segundo, mais voltado para a frustração das expectativas, aqueles que logo passaram a enxergar a escola como espaço onde estavam presentes as exigências, as responsabilidades, as imposições e, consequentemente, a falta de liberdade. Esses sentimentos acompanharam os processos evolutivos da sociedade e se materializaram de diferentes formas no decorrer da História. Os movimentos de luta política se diversificaram, conquistando novos espaços. Alguns, em busca de maior representatividade, filiaram-se, rapidamente, a partidos políticos, enquanto as outras vozes, mais voltadas para o sentimento de pertencimento, ligadas ao cotidiano, encontraram recentemente, nas mídias digitais, um espaço para corporificação dos seus discursos.

Nos últimos anos, a atuação dos sujeitos, nas redes sociais digitais, tornou possível o surgimento de novas formas de organização e realização das manifestações políticas. Tratando-se das questões políticas que envolvem a educação formal no Brasil, julgamos importante pontuar que, ao falarmos em escola imaginária, estamos entrelaçando dimensões complexas que atuam nos

102 espaços de construção do conhecimento, como as práticas metodológicas, as temáticas, os sentimentos de pertencimentos, e as relações entre os sujeitos que, conforme evidenciado pelos movimentos de ocupação, também podem gerar a inclusão ou a exclusão dos sujeitos. Apesar da enorme dimensão geográfica do Brasil que permite a coexistência de escolas com bases estruturantes e práticas metodológicas totalmente diferentes, indagamos: seria possível, hoje, identificar quais os princípios comuns entre elas, ou seja, quais práticas reproduzidas e compartilhadas entre professores, gestores e alunos que ajudam a constituir o imaginário coletivo sobre a educação escolar?

\section{Metodologia}

AEm face desse contexto desafiador, uma Etnografia Virtual foi realizada na página do Facebook Escola da Depressão, com a presença do pesquisador no campo de análise. Durante um período, compreendido entre janeiro e março de 2017, foi realizada uma imersão no Facebook, com visitas sistemáticas e observação das ações dos usuários na página em foco, que 
permitiu um panorama sobre tais ações de uso e a distribuição dos memes na página. Essa margem de tempo foi pensada, previamente, diante do fato de que ela permite contato tanto com o conteúdo produzido no período de férias, quanto com aquele publicado durante os primeiros meses do ano letivo. Para que fosse possível compreender a dinâmica e o fluxo das publicações da Escola da Depressão a partir dos memes, foi preciso adotar um método que permitisse um contato sistemático e organizacional com o material que estava à disposição. Diante disso, duas etapas complementares foram pensadas; a primeira focou na seleção e organização do conteúdo publicado, enquanto a segunda incidiu, especificamente, na análise dos memes. Foram encontrados 450 memes no período de imersão, sistematizados em doze categorias temáticas iniciais (ver Tabela 1), em diálogo com a Análise de conteúdo sugerida por Bardin (1977). Nesse sentido, as análises centraram-se no jogo de enunciados numa perspectiva discursiva crítica.

\section{Tabela 1}

\begin{tabular}{|c|}
\hline Categorias Iniciais \\
\hline Relação Aluno-Aluno \\
\hline Férias \\
\hline Escola X Universidade \\
\hline Processos Avaliativos \\
\hline Futuro \\
\hline Notas \\
\hline Interesse \\
\hline Relação Professor - Aluno \\
\hline Celulares/Internet/Redes Sociais \\
\hline Comportamento \\
\hline Relação Aluno - Família \\
\hline Ações do Aluno \\
\hline Outros (ttemáticas não relacionadas diretamente ao \\
universo escolar) \\
\hline
\end{tabular}

Fonte: produzido pelos autores.

A Etnografia Virtual tem sido adotada como caminho possível para o estudo das relações entre indivíduos e grupos no ambiente virtual e vem se 
distinguindo das outras abordagens porque, primeiro, como afirma Nimrod (201 1), está baseada na análise de textos públicos; segundo, porque se volta para a observação das interações particulares que constituem também a coletividade; e terceiro, porque permite que as análises possam ser feitas, posteriormente, a partir da reunião de um corpus composto por gêneros diversos que, por sua vez, são artefatos importantes nos processos interativos. A escoIha da Etnografia Virtual, como aporte metodológico permite, também, que o pesquisador organize e selecione os objetos mais relevantes para as questões processuais que estão sendo levantadas, e escolha, com mais flexibilidade, os elementos que melhor atendem ao percurso de análise.

Mauss (2003), ao discutir o papel do etnógrafo, diz que a sua atuação está voltada para a observação e para a classificação dos fenômenos. Isso significa que, apesar de serem métodos "indissociáveis" (MARTINS, 2012), principalmente por utilizarem bases conceituais similares em alguns momentos, a Etnografia Virtual nasce da necessidade de contemplar, especificamente, as peculiaridades do ciberespaço.

Para este trabalho, levou-se em consideração a perspectiva de Hine (2005), que não apenas caracteriza e propõe uma práxis voltada para a 104 Etnografia Virtual, como também aponta para alguns problemas, percebidos por quem adota esse tipo de abordagem. $\bigcirc$ principal deles é o fato de que ela ainda é fruto de muitos conceitos herdados das ciências tradicionais, e, por isso, ainda existe muito a ser estudado. A autora, em trabalho intitulado Virtual Ethnography (2000), nos apresenta uma lista com algumas questões que a etnografia virtual pode nos ajudar a compreender melhor. Entre elas, é importante citar: como os usuários da Internet "enxergam" suas capacidades comunicativas e interativas; como a Internet afeta as organizações e relações sociais, com o espaço e com o tempo; quais são as implicações para a autenticidade e segurança; se a experiência do virtual é radicalmente diferente da experiência do real físico.

Hine (2004) reforça que a Etnografia Virtual não é uma transposição categórica do método etnográfico, que se volta para o acompanhamento de atores sociais, já que ela assume que existem diferenças significativas entre o contexto de pesquisa mais tradicional e o virtual, como, por exemplo, a noção de tempo e espaço. 


\section{Análises e resultados}

Sabendo que a escola, também, é uma instituição onde as relações são construídas a partir de expectativas, variando, consideravelmente, de acordo com as funções e os papéis que cada um ocupa dentro da sua rotina, é esperado que os memes evidenciem questões importantes como: hierarquização, vigilância, silenciamento e competitividade. Os professores², por exemplo, são vistos, quase sempre, como agentes de controle, que impedem a liberdade de ir e vir, que determinam prazos, exigem, e avaliam, constantemente, o desempenho individual.

Essa representação do professor nos leva a perceber como as relações sociais estabelecidas no cotidiano "[...] são resultados de representações que são facilmente apreendidas [...]", como defende Moscovici (1978, p. 411. Esse olhar sobre o professor, nos memes, é, "[...] ao mesmo tempo, o produto e o processo de uma atividade mental pela qual um indivíduo ou um grupo reconstitui o real, confrontando e atribuindo uma significação específica" (ABRIC, 1994, p. 188). Por ser processo, essa visão nunca representa a realidade, mas um fragmento dela, uma visão criada por sujeitos que interpretam o mundo e direcionam a comunicação estabelecida entre si a partir do contato com objetos que, paralelamente, são representados. Moscovici (1978) reforça que essas representações não são apenas uma opinião, ou imagens construídas sobre algo, mas também, como aponta Alves-Mazotti (2000, p. 59), " [...] teorias coletivas sobre o real".

No meme Figura 1, curtido po,r aproximadamente, 7,5 mil seguidores, evidenciamos a imagem do professor enquanto agente de controle, na medida em que somente a sua saída permite que os alunos possam ir ao corredor. Foucault (1 999) denunciou, em seus estudos, não só a diagramação e a formatação prisional das escolas, mas também o fato de que as salas de aula estão sempre sob o olhar do professor. 
Figura 1

Meme publicado dia 02 de fevereiro de 2017
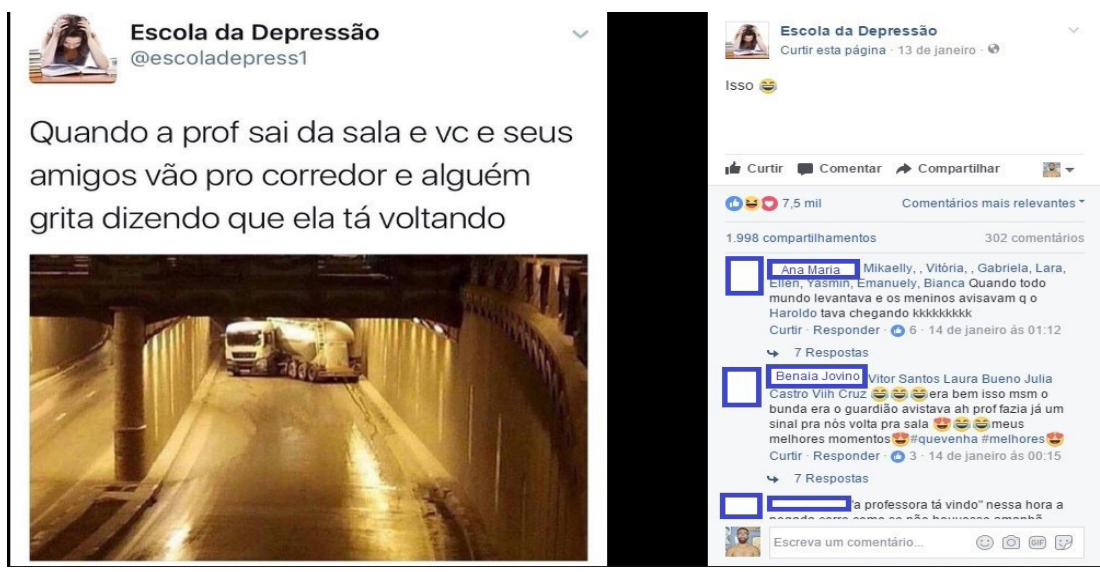

Fonte: Facebook.

A presença física na sala de aula, registrada em atas e diários, torna-se, assim, um dos mecanismos de controle impostos pela escola. A isso, 106 Foucault chama de "micropenalidades do tempo" (FOUCAULT, 1999, p. 159), ou seja, os atrasos, ausências e interrupções das tarefas que fazem parte de uma grande escala de punição. Nos comentários relevantes da postagem, podemos perceber as jovens Ana Maria e Benaia Jovino marcando seus próprios amigos, rememorando eventos similares ocorridos na escola onde estudaram. Não foram identificados nessa categoria memes que estabelecem uma relação de parceria, cumplicidade ou afetividade entre alunos e professores.

Nos memes, também, emergem discursos sinalizando um sentimento de aprisionamento em que certos processos de condicionamento, como, por exemplo, a impossibilidade de frequentar a escola, se manifestam a partir da rotina vivenciada. A maior parte das publicações fala sobre frequência, descrevendo práticas que poderiam estar sendo vivenciadas, caso a escola não existisse. Outros revelam quais as estratégias encontradas e adotadas pelos alunos para lidar com os processos práticos do cotidiano escolar. Memes publicados nas semanas que antecedem o término das férias, até o início de fevereiro, quando as aulas oficialmente começam no Brasil, são essenciais para compreender como esse sentimento de pertença se manifesta. 
meme Figura 2, compartilhado por 3.236 usuários, busca retratar uma situação corriqueira na vida dos estudantes: acordar e ir para a escola. A analogia desse momento com a imagem de um político sendo conduzido à prisão reforça o discurso de que a escola é um lugar indesejado, que encarcera. Percebe-se, nessa categoria ${ }^{3}$ que, além do fato de que vão reencontrar alguns amigos, os aspectos positivos que dizem respeito ao sentimento de pertencimento não são apontados; ir à escola é quase sempre visto como um ato de tortura.

Figura 2

Meme publicado dia 12 de fevereiro de 2017

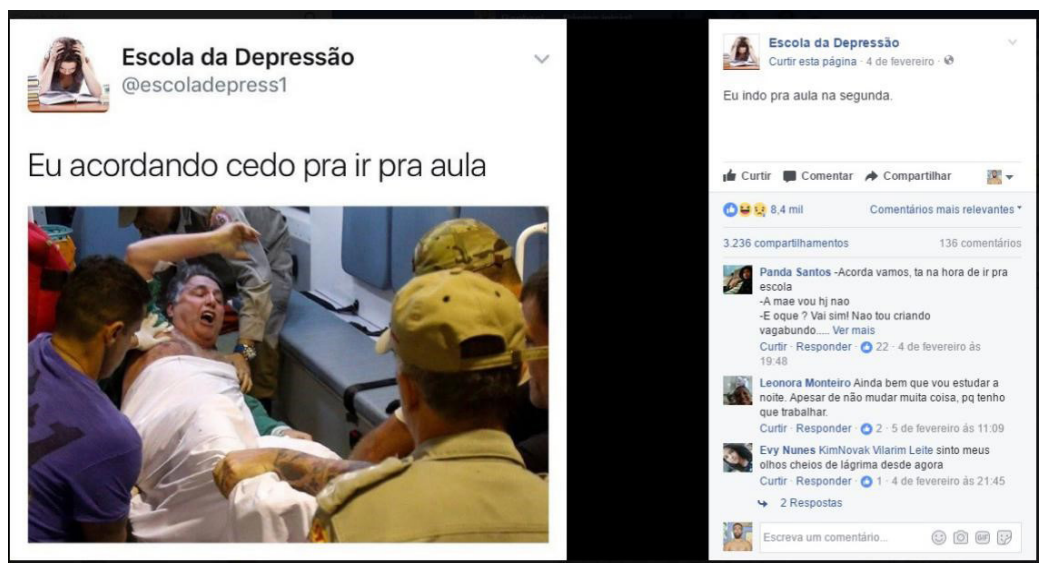

Fonte: Facebook.

Outros memes publicados revelam a visão do aluno diante de práticas avaliativas ainda bastante tradicionais ${ }^{4}$. Trabalhos e provas, sempre cobrados dentro de prazos estabelecidos, são vistos como instrumentos de poder que prenunciam vantagens a partir das notas recebidas. Na mesma medida em que emergem discursos contra esse sistema, surgem outros em que percebemos que os estudantes se veem como sujeitos que precisam atravessar essa etapa. No meme Figura 3, por exemplo, não obstante a alegação de não haver estudado para a prova, a realização da prova é mantida. $\bigcirc$ humor, construído com base na imagem do candidato fora do padrão exigido pelas competições, revela que os memes, ao utilizarem os marcadores textuais "eu e você", retratam o olhar do aluno que, na maioria das vezes, não se adapta às práticas e que, constantemente, refuta e ironiza os contextos. Diante do fato 
de que prazos, trabalhos e provas são instrumentos legitimados, que buscam, de maneira sutil, perpetuar uma realidade em que o aluno se sinta culpado, é surpreendente que os memes sinalizem uma conduta de descrédito, diminuindo o valor social desses indicadores.

Figura 3

Meme publicado dia 01 de janeiro de 2017

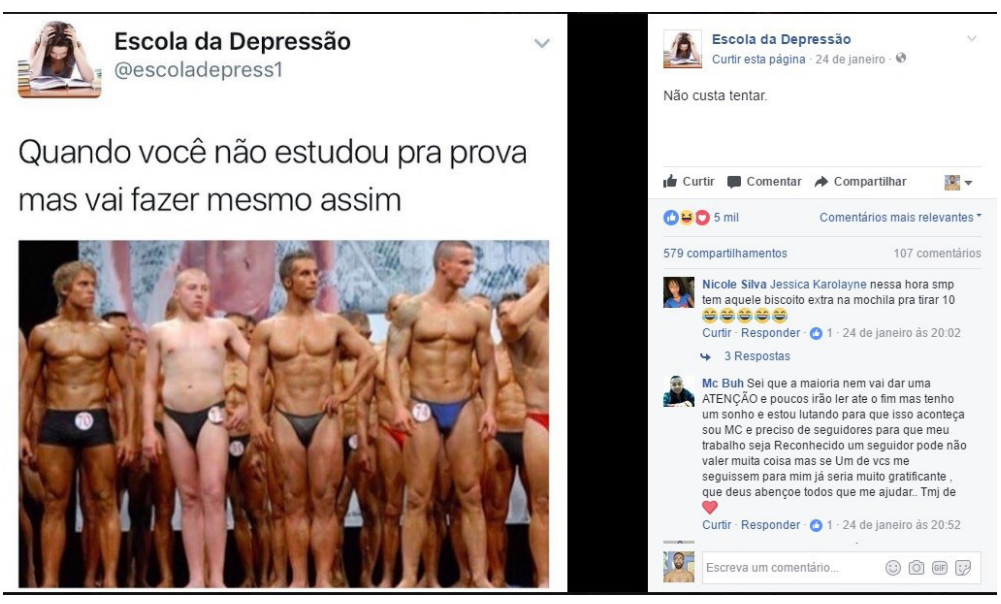

Fonte: Facebook

\section{Considerações finais}

Ao realizarmos um passeio na Escola da Depressão, enxergando-a de perto, registrando e analisando suas marcas discursivas, percebemos como a imaginação sobre os objetos, espaços e relações sociais, ainda reflete ideias tão enraizadas na história, verdades que, de alguma maneira, contaminam as práticas presentes nas nossas vidas até hoje. Dessa maneira, ressaltamos que a construção do imaginário coletivo sobre a escola é um processo, uma ação permanente e dinâmica que, hoje, sofre influência direta dos processos interativos em constante manifestação no ciberespaço.

$\bigcirc$ jogo discursivo permitido por plataformas como o Facebook é, hoje, realizado por sujeitos que buscam apreender e produzir sentidos com base em unidades e sistemas de interação bastante complexos. A onipresença das imagens, nesse espaço, é um fator que quebra a tendência "[...] intecletualista 
que visava libertar-se das imagens [...]" (DURAND, 1984, p. 37) e nos leva a defender estratégias metodológicas em que o papel da imaginação ocupe um lugar de destaque, subvertendo, assim, alguns posicionamentos adotados pela Academia. Através da pesquisa etnográfica realizada, podemos perceber, na pós-modernidade, como a combinação complexa de recursos multimodais abre portas para novas práticas de enunciação, promovendo interseções que nos ajudam tanto a alcançar novos campos imaginários, como a repensar o olhar que lançamos para as manifestações discursivas que giram em torno da educação formal.

Com foco na compreensão do fenômeno, este trabalho refletiu sobre práticas típicas que, hoje, despontam nos espaços virtuais, implicando a produção, reação e compartilhamento de unidades discursivas como os memes. Quando enxergamos os aspectos composicionais desse gênero e a importância que possui nos processos interativos hoje, percebemos como os efeitos de verdade produzido pelos enunciadores, aqui representados pelos administradores da página, são reconhecidos e replicados pela coletividade, corroborando, assim, a sua importância enquanto campo de pesquisa.

Com a possibilidade de ampliar seu nível de interação e conquistar novos seguidores, os agentes, administradores e seguidores, a partir da publicação e do compartilhamento de memes, promovem técnicas de verdade que, conforme Foucault (2010, p. 147), são produtoras e não reflexo da realidade. Quando assumimos que os enunciados são "[...] coisas que se transmitem e se conservam, que têm um valor, e das quais procuramos nos apropriar; que repetimos, reproduzimos e transformamos [...]", desconstruímos a ideia de que as redes sociais são apenas uma representação da realidade e passamos a enxergá-las enquanto parte que the é inerente.

Assumindo que a constante interação entre os sujeitos e as imagens gera uma profusão de significados, identificamos que os discursos construídos sobre a escola nessa página, com base na publicação de memes, utilizam o humor como caminho de elaboração e que essa prática recorrente, muitas vezes, é neutralizada pelas estruturas de poder. Essa questão nos desafia a enxergar o cômico enquanto caminho possível para a promoção de críticas radicais, dirigidas ao poder e aos costumes, como defende Justo (2006). Os memes selecionados na pesquisa indicaram, com base nos agenciamentos de enunciação, que a relação entre os estudantes e a escola está permeada por práticas em que os mecanismos de controle e vigilância se fazem presentes. É 
fundamental reforçar que, apesar do tom sarcástico, a análise das categorias amostrais nos levou a refletir sobre como o sistema educacional ainda exerce uma pressão constante, submetendo os alunos "[...] à subordinação, à docilidade e à atenção nos estudos [...]" (FOUCAULT, 1999, p. 152) a partir de condutas coercitivas e punitivas, fazendo com que eles se sintam cada vez mais distantes da rotina escolar e enxerguem o corpo docente, a família e os métodos avaliativos como extensão ou reprodução dessas práticas.

Paralelamente, é curioso perceber como as manifestações discursivas traduzem, quase sempre, uma visão pessimista sobre escola, não existindo espaço para que ela seja percebida enquanto lugar para a manifestação dos valores igualitários e da liberdade de pensamento. Os temas abordados, quase sempre, giram em torno da deslegitimação do seu papel, não apresentando, explicitamente, propostas para a ruptura ou reestruturação desse modelo. A imaginação, nesse caso, desafia a realidade, mas, conforme afirma Valle (1996, p. 163), ela atua, sobretudo, como uma potência negativa que busca destituir o presente "sem preparar o futuro". Diante do tom de fatalidade adotado, os estudantes, quase sempre, se posicionam como sujeitos que experimentam essa realidade, adotando uma postura de resistência, não conseguindo, por meio

110 da autocrítica, perceber qual o papel que ocupam na permanência e na manutenção dessa lógica.

Imersos na Escola da Depressão e em contato com as vozes que dela eclodem, percebemos como os professores são vistos como agentes cuja carga de competência e experiência dá licença ao "[...] exercício de um domínio que é muito fácil de consagrar nos meios de instituições hierárquicas [...]" (RICOEUR, 1969, p. 721, enquanto as famílias atuam como reprodutoras do sistema econômico, cobrando dos jovens um desempenho passível de aprovação que thes garanta uma boa colocação no mercado de trabalho. Os estudantes estão sempre apontando para os malefícios dos métodos avaliativos e, ao se perceberem como parte de um sistema em que a competividade é um elemento crucial tanto para a sua autopromoção, como para a consolidação de um projeto de futuro idealizado, passam a reproduzir comportamentos que ironizam os sistemas punitivos e as hierarquias, presentes no sistema educacional.

Maffesolli (2001) diz que as imagens podem revelar dimensões profundas da existência coletiva, o que nos leva a perceber que, atuando ou não dentro das redes sociais digitais, a imaginação se mostra como um lugar preparado para o reconhecimento das imagens, nos levando a interrogar os jogos 
de interações discursivas que constroem e permeiam a nossa capacidade de compreensão sobre o papel da escola. Identificar, analisar e promover o contato com as manifestações discursivas dos sujeitos são estratégias vitais para que possamos repensar os métodos, os caminhos de atuação e as práticas exercidas por todos os agentes que participam, ativamente, da escola e das redes de solidariedades semânticas que sobre ela se manifestam.

\section{Notas}

1 De acordo com a Etnografia realizada, vou verificado que a página Escola da Depressão tinha até o dia 14 de junho de 2018 exatamente 2.825.679 curtidas. A segunda página verificada a partir do filtro disponibilizado pelo próprio Facebook que utiliza a palavra chave "escola" em seu título é a Escola de Bolo, voltada para compartilhamento de receitas, com 2.575.270 curtidas, seguida pela Revista Nova Escola, que possuía na mesma data 1.175.432 curtidas. Nova pesquisa, realizada, agora, com a combinação de termos "escola" e "depressão" sugeriu a existência de outras 61 páginas, que totalizam juntas, subtraindo a Escola da depressão, 13,429 curtidas.

2 Na categoria "Relação Professor-Aluno", foram agrupados 41 memes.

3 Na categoria "Interesse", foram agrupados 62 memes.

4 Na categoria "Processos avaliativos", foram reunidos 84 memes.

\section{Referências}

ABRIC, Jean-Claude. Pratiques sociales et représentations. Paris: Presses Universitaires de France, 1994.

ALVES-MAZZOTTI, Alda Judith. Representações sociais: desenvolvimentos atuais e aplicações à educação. In: CANDAU, Vera Maria (Org.). Linguagem: espaços e tempo no ensinar e aprender. Rio de Janeiro, DP\&A, 2000.

ARISTIMUÑO, Felipe. O meme como expressão popular no ensino de arte alguns pensamentos e conceitos base do projeto de pesquisa evms. São Paulo: Revista digital ART, 2014.

BACHELARD, Gaston. A água e os sonhos: ensaio sobre a imaginação da matéria. São Paulo: Martins Fontes, 1998.

BARICHELLO, Eugenia Maria; OLIVEIRA, Cristiane. O marketing viral como estratégia publicitária nas novas ambiências midiáticas. Porto Alegre: Em Questão, 2010.

BARDIN, Laurence. Análise de conteúdo. Lisboa: Edições 70, 1977. 
BLACKMORE, Susan. The meme machine. Oxford, Reino Unido: Oxford University Press, 2000.

BURGESS, Jean. GREEN, Joshua. YouTube e a revolução digital: como o maior fenômeno da cultura participativa transformou a mídia e a sociedade. São Paulo: Aleph, 2009.

CARRINGTON, P. J.; SCOTT, J.; WASSERMAN, S. Models and methods in social networkanalysis. Cambridge: Cambridge University Press, 2005.

CASTELLS, Manuel. A galáxia da internet: reflexões sobre a Internet, os negócios e a sociedade. Rio de Janeiro, Oxford University Press, 2006.

CORDEIRO. William Robson; COSTA, Luciano. Jornalismo imersivo: Perspectivas para novos formatos. Leituras do Jornalismo, FAAC-UNESP, São Paulo, 2016.

CARDOSO, Gustavo. A mídia na sociedade em rede: filtros, vitrines, notícias. Rio de Janeiro: FGV, 2007.

DAWKINS, Richard. O gene egoísta. Editora Gradiva, Portugal, 1979.

DENNETT, Daniel. Darwin's Dangerous Idea. London: Penguin 1996.

DURAND, Gilbert. As estruturas antropológicas do imaginário: introdução à arquetipologia. São Paulo: Martins Fontes, 1997.

La foi ducordonnier. Paris: Denoël, 1984

FONTANELLA, Fernando Israel. $\bigcirc$ que é um meme na Internet? Proposta para uma problemática da memesfera. In: SIMPÓSIO NACIONAL (ABCiber), 3; 2009, São Paulo. Anais.. São Paulo: III Simpósio Nacional da ABCiber, 2009.

FOUCAULT, Michel. Vigiar e punir: a história da violência nas prisões. Petrópolis: Vozes, 1999.

A hermenêutica do sujeito. São Paulo: Martins Fontes, 2010.

HINE. Cristine. Etnografía virtual. Barcelona: Editora UOC, 2004.

JENKINS, Henry. Cultura da convergência. São Paulo: Aleph, 2009.

JUSTO, José Sterza. Humor, educação e pós-modernidade. In: ARANTES, Valéria Amorin. (Org.). Humor e alegria na educação. São Paulo: Summus, 2006.

LACAN, Jacques. O simbólico, o imaginário e o real. Em Nomes-do-Pai. Rio de Janeiro, 2005

LÉVY, Pierre. Cibercultura. São Paulo: Editora 34, 2000. 
MARTINO, Luis Mauro Sá. Teoria das mídias digitais: linguagens, ambientes, redes. 2. Petrópolis: Vozes, 2015.

MAFFESOLl, Michel. A transfiguração do político: a tribalização do mundo. Porto Alegre: Sulina, 2001.

MARTINS, Tatiane Marques de Oliveira. A netnografia como metodologia para conhecer o trabalho de professores da cultura digital. UNIESPE, 2012. Disponível em: https:// goo.gl/y3Xn8b. Acesso em: 23 jul. 2017.

MAUSS, Marcel. Sociologia e antropologia. São Paulo: Cosac \& Naify, 2003.

MOSCOVICl, Serge. A representação social da psicanálise. Tradução Álvaro Cabral. Rio de Janeiro: Zahar, 1978.

NIMROD, Galit. The funculture in seniors' online communities. The Gerontologist, 2011. Disponível em: https://goo.gl/go95×3. Acesso em: 16 out. 2016.

PERUZZO, Cicilia. Comunidades em tempo de redes. Comunicação e movimentos populares: quais redes, 2002. Disponível em: https://goo.gl/PiFKpM. Acesso em: 1 jan. 18.

POSSENTI, Sírio. Os humores da língua: análises lingüísticas de piadas. Campinas: Mercado de Letras, 2005.

RECUERO, Raquel. Redes sociais na internet. Porto Alegre: Sulina, 2009.

RICOEUR, Paul. Reconstruir a universidade. Rio de Janeiro: Revista Paz e Terra/Editora Civilização Brasileira, 1969.

SAVIANI, Dermeval. A nova lei da educação: trajetória, limites e perspectivas. Campinas: Autores Associados, 2004.

SCHUABB, Paula Alexandre. Memes de internet e suas temporalidades de produção o e consumo. Rio de Janeiro: SPGD, 2016.

SHIFMAN, Limor. Memes in digital culture. Massachusetts: MIT Press, 2013.

SOUZA, Carlos Fabiano de. Memes: formações discursivas que ecoam no ciberespaço. Campos dos Goytacazes: VÉRTICES, 2013.

SOUZA, Luciana. Com a palavra, a imagem. Revista Virtual de Letras, 2009. Disponível em: https://goo.gl/igsfuc. Acesso em: 3 nov. 2017.

TORRES, Claudio. A bíblia do marketing digital. São Paulo: Novatec, 2009.

VALE, Lilian do. A escola imaginária. Rio de Janeiro: DP\&Editora, 1997.

VAN LEEUWEN, Theo. Multimodality. In: SIMPSON, James (Ed.). New York: Routledge, 2011 . 
WASSERMAN, Stanley; FAUST, Katherine. Social network analysis. Methods and applications. Cambridge: Cambridge University Press, 1994.

Prof. Ms. Raphael Alves da Silva Universidade Federal Rural de Pernambuco Fundação Joaquim Nabuco E-mail: raphael.memetizando@gmail.com Prof. ${ }^{a}$ Dr. ${ }^{a}$ Flavia Mendes de Andrade e Peres Universidade Federal de Pernambuco Departamento de Educação

Programa de Pós-Graduação em Educação Culturas e Identidades Grupo de Pesquisas Educação Ambiental, Docência e Questões Contemporâneas E-mail: peres.flavia@gmail.com

Recebido 11 jun. 2018 Aceito 24 ago. 2018 